UDC 678-19:539.3

\title{
REACTIVE EXTRUSION OF DYNAMIC ELASTOPLASTICS ON THE BASIS OF THERMOPLASTIC POLYOLEFINS AND BUTYL RUBBER
}

\author{
Z.N. Guseynova, N.T. Kahramanov, A.A. Hasanova, Kh.V. Allahverdiyeva, \\ F.A. Mustafayeva, *V.S. Osipchik \\ Institute of Polymer Materials National Academy of Sciences of Azerbaijan \\ 124, S.Vurgun str., AZ 5004, Sumgait; e-mail: najaf1946@ rambler.ru \\ $* D$. Mendeleev University of Chemical Technology of Russia \\ Miusskaya sq.9, 125047, Moscow, Russia
}

\author{
Received 23.04.2019
}

\begin{abstract}
The article deals with the influence of the concentration of butyl rubber and vulcanizing agents on the process of reactive extrusion of elastoplastics based on a mixture of thermoplastic polyolefins. The mechanic-chemical synthesis of dynamically vulcanized elastoplastics was carried out in the process of reactive extrusions. Single screw extruder with ratio $L / D=24$ consists of 4 zones: loading zone, compression zone, dosing zone, extruder head. The number of turnovers of the screw was regulated using an asynchronous engine. The head is equipped with a slotted console enabling to obtain continuous sheets $2 \mathrm{~mm}$ thick and $100 \mathrm{~mm}$ wide. As thermoplastic polyolefins there was used the polyethylene of low density, polypropylene. Vulcanization of polymer mixtures was carried out using the dicumyl peroxide and sulfur. The mechanochemical synthesis of elastoplastics was carried out at different temperatures of the zones of material cylinder and extrusion pressure. The results of the study of the influence of extrusion process parameters on the melt flow rate of elastoplastics were presented. For a mixture of polyethylene and butyl rubber of low density the optimum temperature for zones of the material cylinder varied within $100-150^{\circ} \mathrm{C}$, and the extrusion pressure was $5.2-7.0 \mathrm{MPa}$. For a mixture of polypropylene and butyl rubber the temperature regime varied within $140-210^{\circ} \mathrm{C}$ and pressure of extrusion - 7.2-9.4 MPa. To add elastoplastic properties to the polymer mixtures, vulcanizing agents such as dicumyl peroxide and sulfur were introduced into their composition. Selective influence of vulcanizing agents on the nature of changes of technological parameters of reactive extrusion and melt flow index was investigated. It found that dynamic vulcanic elastoplastics with unique compatibility of structures and properties can be obtained in at concentrations of dicumyl peroxide $-0.5 \mathrm{wt} . \%$ or sulfur-5.0wt.\%. It revealed that dynamic vulcanic elastoplastics with unique compatibility of structures and properties can be obtained in the concentration of dicumyl peroxide- $0.5 \mathrm{wt} . \%$ or sulfur-5.0wt. \%. It established that the concentration of butyl rubber in the mixture of $L D P E+P P-10,20,30,40 \mathrm{wt}$.\% softening temperature, according to thermo-mechanical tests, varies accordingly in the range of $125,107,89,78{ }^{\circ} \mathrm{C}$.
\end{abstract}

Keywords: ultimate stress limit, modification, dynamic elastoplastics, relative extension

DOI: 10.32737/2221-8688-2019-2-267-274

\section{Introduction}

Research into the development of new types of polymeric materials with their sometimes unexpected and useful properties, is markedly affected by a set of measures aimed at improving and developing modern industries. Currently, one of the actual tasks is to conduct theoretical and experimental research, which opens up the possibility of obtaining materials with predetermined performance characteristics. Of course, at present one of the most promising polymeric materials are thermoplastic elastomers (TPE) obtained by the method of dynamic vulcanization. Otherwise, they are called "dynamic" elastoplastics (DVEP). The latter circumstance became possible due to the mixing of polymers of different nature produced in the polymer industry [1-4]. It was possible to have a significant impact on changes in micro- and macrostructure of the 
composite materials obtained, and, accordingly, their properties. In this regard, the most promising direction is the mechanochemical synthesis of DVEP based on multicomponent polymer blends, which are characterized by a unique combination of structure and performance properties. With properties of rubber and the ability to process the thermoplastics on standard equipment,
DVEP has become an indispensable material for obtaining on its basis structural products for special purposes [5].

All things considered, the purpose of this work is to study the influence of the technological aspects of reactive extrusion on the process of obtaining DVEP based on nonpolar polyolefin composite systems.

\section{Experimental part}

The object of the study was to explore the low-density polyethylene (LDPE) with ultimate tensile stress - 13.3 $\mathrm{MPa}$, elongation at break $-512 \%$, melting point $-102^{\circ} \mathrm{C}$, and melt flow index (MFI) - $1.3 \mathrm{~g} / 10 \mathrm{~min}$.

PP brand PP 1500P, melting point $160^{\circ} \mathrm{C}$, Vicat softening point $148^{\circ} \mathrm{C}$, flexural modulus $1400 \mathrm{MPa}$, ultimate tensile stress $32.0 \mathrm{MPa}$, elongation at break $20 \%$, MFI is 2.2 $\mathrm{g} / 10 \mathrm{~min}$ at $190^{\circ} \mathrm{C}$.

Butyl rubber (BR) was used as elastomer.

Dicumyl peroxide (DP) is a light yellow powder, $\mathrm{T}_{\mathrm{m}}=40^{\circ} \mathrm{C}$ and used as a polymer Cross-linking agent.

Sulfur is used as a vulcanizing agent for polymer blends.

The MFI was determined on a rheometer of the MELT FLOW TESTER brand, CEAST MF50 (INSTRON, Italy) at a temperature of $190^{\circ} \mathrm{C}$ and a load of $5 \mathrm{~kg}$.

Tensile yield strength, ultimate tensile stress and elongation at break were determined in accordance with GOST 11262-80.

The melting point was determined on Paulik, Paulik and Erdei derivatograph.

Thermo-mechanical properties were determined on a Kanavts device. Deformation was measured at consistently changing temperatures. Thermo-mechanical studies make it possible to obtain information about all possible physical, physicochemical, and chemical changes occurring in samples during temperature variations of the experiment and, thus, to obtain additional data on temperature transitions that are important for polymer processing.

The mechanochemical synthesis of dynamically vulcanized elastoplastics was carried out in the course of the reactive extrusion process. Single screw extruder with ratio $\mathrm{L} / \mathrm{D}=24$ consist of 4 zones: loading zone, compression zone, dosing zone, extruder head. The number of screw turnovers was regulated using an asynchronous motor. The head is equipped with a slotted console which allows obtaining continuous sheets $2 \mathrm{~mm}$ thick and $100 \mathrm{~mm}$ wide. The blades were cut from these sheets to determine the strength characteristics and the elongation at break of polymer composites. After dry mixing of the components in a ball mill, $\mathrm{LDPE}+\mathrm{PP}+\mathrm{BR}+$ DP (or sulfur) was loaded into the extruder through the loading zone. The temperature of the material cylinder was selected depending on the type and ratio of the components of the polymer mixture.

\section{Results and discussion}

In order to obtain dynamic elastoplastics, this paper discusses the effect of the technological parameters of reactive extrusion on the properties of polymer blends based on thermoplastic polyolefins (LDPE + PP) and butyl rubber. For this to happen,
Table-1 first presents the results of experimental studies for bi-component polymer systems LDPE+BR and PP+BR. The analysis of the results of the research in line with the Table makes it possible to establish that regardless of the type of polyolefin, the 
loading of BR leads to an increase in melt increase in the extrusion pressure as the viscosity. This is confirmed by the concentration of the elastomer component monotonous decrease in the MFI and the rises in the mixture of LDPE+BR and PP+BR.

Table 1. Optimum temperature extrusion conditions of bi-component systems based on the mixture of thermoplastic polyolefin LDPE, PP and BR

\begin{tabular}{|c|c|c|c|c|}
\hline Composition, wt.\% & $\begin{array}{c}\text { Extrusion temperature } \\
\text { in cylinder zones, T, } \\
\text { C }\end{array}$ & $\begin{array}{c}\text { Extrusion } \\
\text { pressure, } \\
\text { MPa }\end{array}$ & $\begin{array}{c}\text { Number of } \\
\text { screw } \\
\text { turnovers } \\
\text { turnover / min }\end{array}$ & $\begin{array}{c}\text { Melt flow } \\
\text { index, } \\
\text { g/10 min }\end{array}$ \\
\hline LDPE & $100-120-140-150^{*}$ & 5.2 & 13 & 1.30 \\
LDPE+10BR & $100-120-140-150^{*}$ & 5.5 & 15 & 1.24 \\
LDPE+20 BR & $100-115-135-150^{*}$ & 6.4 & 15 & 1.27 \\
LDPE+30 BR & $100-115-130-145^{*}$ & 7.0 & 15 & 1.18 \\
LDPE+40 BR & $100-115-130-140^{*}$ & 7.0 & 15 & 1.06 \\
PP & $140-160-180-210^{*}$ & 7.2 & 16 & 2.20 \\
PP+10 BR & $140-160-180-210^{*}$ & 7.5 & 18 & 2.18 \\
PP+20 BR & $140-160-175-205^{*}$ & 7.9 & 18 & 1.92 \\
PP+30 BR & $140-160-170-205^{*}$ & 8.3 & 18 & 1.64 \\
PP+40 BR & $140-160-170-200^{*}$ & 8.8 & 18 & 1.44 \\
PP+50 BR & $140-155-165-200^{*}$ & 9.4 & 18 & 1.12 \\
\hline
\end{tabular}

*extruder head temperature

To add elastoplastic properties to polymer compositions, the most effective method is the use of cross-linking agents [5-7]. However, depending on the type and concentration of Cross-linking agents in the process of reactive extrusion, it is possible to obtain dynamically vulcanized elastoplastics (DVEP). In order to clarify the separate influence of Cross-linking on technological features of the reactive extrusion process of the above-mentioned bicomponent polymer systems, optimum concentrations of dicumyl peroxide were used as vulcanizing agent in the amount of $0.5 \mathrm{wt} . \%$ and sulfur in the amount of $5.0 \mathrm{wt} . \%$.

Table 2. Optimum temperature conditions in the extrusion of DVEP based on mixture of thermoplastic polyolefins (LDPE and PP) and BR

\begin{tabular}{|c|c|c|c|c|}
\hline Composition, wt.\% & $\begin{array}{c}\text { Extrusion } \\
\text { temperature in } \\
\text { cylinder zones, T, C }\end{array}$ & $\begin{array}{c}\text { Extrusion } \\
\text { pressure, } \\
\text { MPa }\end{array}$ & $\begin{array}{c}\text { Number of } \\
\text { screw } \\
\text { turnovers, } \\
\text { turnover / min }\end{array}$ & $\begin{array}{c}\text { Melt flow } \\
\text { index, } \\
\text { g/10 min }\end{array}$ \\
\hline LDPE +10 BR+0.5 DP & $100-120-140-155^{*}$ & 5.9 & 15 & 1.08 \\
LDPE +20 BR +0.5 DP & $100-115-135-155^{*}$ & 6.8 & 15 & 0.88 \\
LDPE +30 BR +0.5 DP & $100-115-135-150^{*}$ & 7.6 & 15 & 0.75 \\
LDPE +40 BR +0.5 DP & $100-115-130-150^{*}$ & 7.9 & 15 & 0.48 \\
PP+10 BR +0.5 DP & $140-170-185-210^{*}$ & 8.5 & 18 & 2.03 \\
PP +20 BR +0.5 DP & $140-165-175-205^{*}$ & 8.9 & 18 & 1.92 \\
PP +30 BR +0.5 DP & $140-160-170-205^{*}$ & 9.4 & 18 & 1.64 \\
PP +40 BR +0.5 DP & $140-160-170-200^{*}$ & 9.8 & 18 & 1.44 \\
PP +50 BR +0.5ПД & $140-155-165-200^{*}$ & 10.7 & 18 & 1.12 \\
LDPE +10 BR +5 sulfur & $100-120-140-155^{*}$ & 5.7 & 14 & 1.18 \\
LDPE +20 BR +5 sulfur & $100-120-135-155^{*}$ & 6.5 & 14 & 0.99 \\
LDPE +30 BR +5 sulfur & $100-115-135-155^{*}$ & 7.3 & 14 & 0.86 \\
\hline
\end{tabular}




\begin{tabular}{|c|c|c|c|c|}
\hline LDPE +40 BR +5 sulfur & $100-115-135-150^{*}$ & 7.6 & 14 & 0.61 \\
PP +10 BR +5 sulfur & $140-170-185-210^{*}$ & 8.2 & 17 & 2.21 \\
PP +20 BR +5 sulfur & $140-165-180-205^{*}$ & 8.5 & 17 & 2.05 \\
PP +30 BR +5 sulfur & $140-165-175-205^{*}$ & 9.0 & 17 & 1.86 \\
PP +40 BR +5 sulfur & $140-160-170-200^{*}$ & 9.5 & 18 & 1.62 \\
PP +50 BR +5 sulfur & $140-160-165-200^{*}$ & 10.2 & 18 & 1.38 \\
\hline
\end{tabular}

*extruder head temperature

The comparison of the data presented in Table-2 makes it possible to note that along with the loading of DP and sulfur into the composition, a regular decrease in MFI of DVEP is observed which might be caused by an increase in the melt viscosity due to the formation of a rare-mesh spatial cross-linked structure. At the same time, it is characteristic that the processing of sulfur vulcanized DVEP is carried out under relatively low temperature conditions. This is explained as being due to the fact that when compared with samples of crosslinked DP, the use of sulfur as a vulcanizing agent does not lead to sharp decrease in the MFI of DVEP. All this finds endorsement in the fact that during peroxide vulcanization, short $-\mathrm{C}-\mathrm{C}-$ bonds are formed, and during sulfur vulcanization, relatively long eight-membered cross bonds are formed $\left(S_{8}\right)$. The latter circumstance contributes to rise in flexibility and conformational mobility of macrochains which has a positive effect on the MFI capillary in the uniaxial direction.

Account has to be taken of the fact that the extrusion of cross-linked polymeric materials is carried out at relatively high screw turnovers. The reason is that when processing cross-linked polymer systems with low melt flow it is necessary to set some pressure in the material of extruder cylinder which is formed by raising the number of screw turnovers. Therefore, when choosing the technological mode of sulfur vulcanization extrusion, their processing is carried out at relatively lower pressure and the increased number of screw turnovers. This technology also provides significant energy savings.

Very often, in the development of DVEP with improved physic-mechanical properties the preference is given to the use of multicomponent polymer systems. The use of the mentioned polymer system makes it possible to obtain a composite material that combines beneficial properties of each mixture component thus opening up the possibility for obtaining a DVEP with a rather wide range of performance characteristics

Table- 3 presents the results of the study into technological features of the extrusion of multicomponent polymer systems based on a LDPE+PP+BR mixture. For example, polymer systems with a ratio of LDPE:PP $=50: 50$ are used as an object of study. The choice of such a ratio of thermoplastic polyolefin was due to the necessity of imparting the characteristic properties of rubbers to elastoplastics and DVEP thereupon.

Table 3. The influence of the BR concentration on technological mode of extrusion in ternary mixture of polyolefin (LDPE + PP + BR)

\begin{tabular}{|c|c|c|c|c|}
\hline Composition, wt.\% & $\begin{array}{c}\text { Extrusion } \\
\text { temperature in } \\
\text { cylinder zones, T, C }\end{array}$ & $\begin{array}{c}\text { Extrusion } \\
\text { pressure, } \\
\mathrm{MPa}\end{array}$ & $\begin{array}{c}\text { Number of } \\
\text { screw } \\
\text { turnovers, } \\
\text { turnover / min }\end{array}$ & $\begin{array}{c}\text { Melt flow } \\
\text { index, } \\
\text { g/10 min }\end{array}$ \\
\hline 45LDPE+45PP+10BR & $120-140-170-205^{*}$ & 5.5 & 13 & 1.72 \\
40LDPE+40PP+20BR & $120-140-160-200^{*}$ & 6.2 & 13 & 1.46 \\
35LDPE+35PP+30BR & $110-140-160-195^{*}$ & 6.6 & 13 & 1.31 \\
30LDPE+30PP+40BR & $110-140-160-195^{*}$ & 7.1 & 14 & 1.07 \\
\hline
\end{tabular}

*extruder head temperature 
The fact is that LDPE is a relatively elastic and soft thermoplastic, which has high values of elongation at break. At the same time, PP is a relatively rigid and durable polymer with relatively low values of elongation at break. Analysis of the data given in Table- 3 reveals that as the concentration of BR rises, there is a regular increase in the extrusion pressure in the material cylinder at nearly constant number of screw turnovers. In addition, after the fact of the MFI sample reduction in MFI samples was established this can be interpreted as rise in the melt viscosity. The increase in melt viscosity in this case is due to the fact that the elastomeric component is characterized by a relatively high molecular weight equal to 220000 in respect of LDPE and PP. And, the more BR is loaded into the LDPE + PP mixture, the higher the viscosity of the polymer composition becomes. The Table provides optimal temperature conditions for extrusion into zones of the material cylinder. According to the data obtained, as the concentration of BR increases from 10 to 50 wt. \% the temperature in the extruder head falls from 205 to $195^{\circ} \mathrm{C}$. The temperature reduction in the extruder head is a necessary measure, since with the BR loading into the composition of thermoplastic polyolefin, a noticeable decrease in the softening temperature of the polymer mass of the threecomponent system was revealed in the thermomechanical analysis. For example, when the BR concentration in the mixture of LDPE+PP- 10, 20, 30, 40 wt.\% softening temperature, varies accordingly in the range $125,107,89,78{ }^{\circ} \mathrm{C}$, according to thermomechanical tests

To obtain a DVEP based on threecomponent polymer systems, it was interesting to investigate the effect of DP and sulfur on the process of reactive extrusion. In the literature, there are works on the preparation of DVEP-based mixture of polymers; however, research into the selection of optimal conditions for their processing by extrusion method, especially reactive extrusion, is rather limited [5]. In the course of the reactive extrusion process, chemical cross-linking of macrochains of polyolefin mixtures proceeds with the participation of such vulcanizing agents as DP and sulfur. Depending on the concentration of DP, vulcanization can proceed through the use of various mechanisms. Cross-linking can occur at two points: breaking double bonds and separating a hydrogen atom from tertiary or secondary carbon atoms that are in $\alpha$-position to the double bond. It should be noted that the activation energy of breaking double bonds is approximately 9-17 kJ / mol, while the activation energy of hydrogen atom detachment at the tertiary carbon atom is 38$46 \mathrm{~kJ} / \mathrm{mol}$. From thermodynamic point of view, the most preferred mechanism of crosslinking is the formation of $-\mathrm{C}-\mathrm{C}-$ cross-bonds at the point of breaking double bonds in the macro-chain of polymers. The concentration of double bonds in BR is approximately $2-3 \%$ mol. which is much higher than the total content of vinyl groups (terminal and transvinylene groups) in LDPE and PP. In all cases, the vulcanization mechanism will, to a certain extent, depend on the DP concentration. When the DP concentration is up to $0.5 \mathrm{wt} . \%$. The cross-linking process proceeds predominantly through the double bonds of the elastomeric component which creates conditions for the formation of dynamic elastoplasts. When the DP concentration is more than 0.5 wt. $\%$ the cross-linking and the formation of $-\mathrm{C}-\mathrm{C}-$ cross-bonds occurs by a mixed mechanism: by means of vinyl groups and through tertiary carbon atoms between elastomer macrochains, between thermoplastic polyolefin macro-chains, and between elastomer and thermoplastic macro-chains. The formation of chemically cross-linked spatial structure significantly reduces the crystallinity of DVEP and melt' flow. For example, with the DP loading in the amount of $0.5,1.0,2.0 \mathrm{wt} . \%$ the content of the gel fraction in DVEP accordingly changes in the following sequence: 13 wt. $\%, 45$ wt. $\%$ and 72 wt. $\%$.

Table-4 presents the results of research into optimal conditions for the reactive extrusion of multicomponent DVEP. In this case, the effect of DP concentration and sulfur on the extrusion process, and such technological characteristics as MFI was 
investigated. A comparative analysis of the experimental data reveals that the use of vulcanizing systems is accompanied by drop in the temperature of extrusion condition. This is explained as being due to the fact that as the DP concentration and the melt viscosity increases, the temperature rise in the material cylinder of the extruder becomes undesirable. The high temperature of the melt at the exit of the extruder head and decomposition of the DP with the release of $\mathrm{CO}_{2}$ leads to a sharp swelling of the extrudate and the formation of partially foamed material. Therefore, in the course of processing, the temperature of the melt composition rose due to the middle zones of the material cylinder.

As noted above, the basis of the DVEP reactive extrusion is a mono-technology which contributes not only to the process behavior in line with one-pass scheme but also to DVEP obtaining with uniformly dispersed polymer components in a mixture and, accordingly, with more stable properties.

The use of sulfur as a vulcanizing agent provides even more interesting and encouraging results. This is explained as being due to the fact that sulfur vulcanization allows processing polymeric material at softer temperature conditions. The MFI of DVEP samples after sulfur vulcanization is kept at a relatively high level which also provides the possibility of carrying out the reactive extrusion in the presence of sulfur at a wider temperature range.

Table-4. The influence of DP concentration on the technological mode of DVEP extrusion (30\% $\mathrm{LDPE}+30 \% \mathrm{PP}+40 \% \mathrm{BR}+\mathrm{DP})$

\begin{tabular}{|c|c|c|c|c|}
\hline $\begin{array}{c}\text { Composition of the polymer } \\
\text { mixture, wt.\% }\end{array}$ & $\begin{array}{c}\text { Extrusion } \\
\text { temperature in } \\
\text { cylinder zones, T, C }\end{array}$ & $\begin{array}{c}\text { Extrusion } \\
\text { pressure, } \\
\text { MPa }\end{array}$ & $\begin{array}{c}\text { Number of } \\
\text { screw } \\
\text { turnovers, } \\
\text { turnover / } \\
\text { min }\end{array}$ & $\begin{array}{c}\text { Melt flow } \\
\text { index, } \\
\mathrm{g} / 10 \text { min }\end{array}$ \\
\hline 30LDPE+30PP+40BR(PM) & $110-140-160-195^{*}$ & 7.1 & 14 & 1.07 \\
PM +0.5 DP & $120-140-160-195^{*}$ & 7.9 & 14 & 0.65 \\
PM +1.0 DP & $120-145-155-195^{*}$ & 10.4 & 14 & 0.18 \\
PM +1.5 DP & $130-150-160-190^{*}$ & 12.6 & 14 & 0.06 \\
PM +2.0 DP & not reprocessed & - & - & 0 \\
PM +1.0 sulfur & $110-140-160-190^{*}$ & 6.8 & 14 & 0.99 \\
PM +2.0 sulfur & $110-135-155-190^{*}$ & 7.0 & 14 & 0.85 \\
PM +3.0 sulfur & $110-135-150-185^{*}$ & 7.4 & 14 & 0.66 \\
PM +5.0 sulfur & $110-140-150-185^{*}$ & 7.9 & 14 & 0.55 \\
PM +10.0 sulfur & $110-140-160-185^{*}$ & 8.6 & 14 & 0.37 \\
\hline
\end{tabular}

*extruder head temperature

Thus, on the basis of the above, we can conclude that the technology of thermoplastic polyolefin and butyl rubber-based reactive extrusion of DVEP was studied. The mixture of polymer components, with their simultaneous vulcanization in terms of monotechnology, showed that the process of selective cross-linking by double bonds of BR is most effective when the DP concentration is not more than 0.5 wt. $\%$ and sulfur not more than 5.0 wt.\%. At the same time, the synthesized elastoplastics are processed as thermoplastics with rubber properties.

\section{References}

1. Nguen Min' Tuan, Chalaya N.M., Osipchik V.S. Structure and physico-mechanical properties of mixtures of polypropylene and metallocene ethylene-propylene elastomer. Plasticheskie massy-Plastics. 2017, no. 9- 
10, pp.12-16.(In Russian)

2. Simonov-Emel'yanov I.D. Principles of creation and processing of composite materials dispersed structure. Plasticheskie massy-Plastics. 2005, no. 1, pp.11-16. (In Russian)

3. Kravchenko T.P., Ermakov S.N., Kerber M.L. et al. Scientific and technical problems of obtaining composite materials based on structural thermoplastics. Plasticheskie massy-Plastics. 2010, no. 10, pp.32-37. (In Russian)

4. Kahramanly Yu.N. Incompatible polymer blends and composite materials based on them. Baku: Elm Publ. 2013, 152 p. (In Azerbaijan)

5. Vol'fson S.I. Dynamically vulcanized thermoplastic elastomers: obtaining, processing, properties. Moscow: Nauka Publ. 2004, 173 p. (In Russian)

6. Kazakov Yu.M., Volkov A.M., Ryzhikova I.G., Bauman N.A., Vol'fson S.I. Binary mixtures of ethylene $\alpha$-olefin elastomers to improve the balance of impact and strainstrength characteristics of polypropylene compositions obtained in the process of reactive extrusion. Plasticheskie massy-Plastics. 2016, no. 9-10, pp. 3-6. (In Russian)

7. Kazanchan A.Eh., Osipchik V.S., Chalaya N.M., Kikel' V.A. Modifying the properties of chemically cross-linked polyethylene by thermoplastic elastomers. Plasticheskie massy-Plastics. 2012, no. 1, pp.3-7. (In Russian)

\title{
TERMOPLASTIK POLIOLEFİNLOR VӘ BUTIL KAUÇUKU OSASINDA DİNAMIKK ELASTOPLASTLARIN REAKSIYYALI EKSTRUZIYASI
}

\author{
Z.N. Hüseynova, N.T. Qəhromanov, A.Ө. Hosənova, X.V. Allahverdiyeva, \\ F.A. Mustafayeva, *V.S. Osipçik \\ AMEA Polimer Materialları Institutu \\ AZ 5004 Sumqaylt, S.Vurğun küç., 124; e-mail: najaf1946@rambler.ru \\ *D.I. Mendeleyev adina Rusiya Kimya-Texnologiya Universiteti
}

Butil kauçuku vo vulkanlaşdırıcı agentlarin (dikumil peroksid vo kükürd) miqdarının aşağı sıxlıqlı polietilen va polipropilen qarışı̆̆ asasında elastoplastların ekstruziyasının texnoloji prosesino təsiri nazardan keçeirilmişdir. Dinamik vulkanlaşmış elastoplastların mexanokimyəvi sintezi reaksiyalı ekstruziya prosesində hayata keçirilmişdir. $L / D=24$ nisbətli birşnekli ekstruder 4 zonadan ibarətdir: yüklama zonası, sıxılma zonası, ölçü zonası, ekstruder bașlı̆̆l. Snekin dövrlarinin sayı asinxron müharrikla tənzimlanmişdir. Termoplastik poliolefin olaraq așağl sixlıqlı polietilen, polipropilendan istifadə olunmuşdur. Polimer qarışlqların vulkanlaşdırlması dikumil peroksid vo kükürd istifado olunmaqla hayata keçirilmişdir. Elastoplastların mexanokimyəvi sintezi material silindrinin müxtəlif zonalarının müxtəlif temperaturlarında vo ekstruziya təzyiqlarinda aparılmışdır. Ekstruziya prosesi parametrlarinin elastoplastların arintinin axıcılıq göstoricisina tosiri tadqiqatlarının noticalori təqdim olunmuşdur. Aşağı slxlıqlı polietilen və butil kauçuk qarışı̆̆ ü̧̈ün material silindrin zonaları üzrə temperatur rejimi 100-150 ${ }^{\circ}$, ekstruziya tazyiqi isa 5.2-7.0 MPa intervalında dəyişmişdir. Propilen vo butil kauçuk qarışığı üçün temperatur rejimi $140-210^{\circ} \mathrm{C}$, ekstruziya təzyiqi isa 7.2-9.4 MPa intervalında dəyişmişdir. Polimer qarışıqlara elastoplast xüsusiyyətlarin verilməsi üçün onların tərkibinə dikumil peroksid vo kükürd kimi vulkanlaşdırıcı agentlar daxil edilmişdir. Vulkanlaşdırıcı agentin reaksiyalı ekstruziyanın texnoloji parametrlarina vo arintinin axıcıllq göstaricisina selektiv tasiri öyranilmişdir. Müəyyən olunmuşdur ki, unikal quruluş vo torkib uyğunluqlu dinamik vulkanik elastoplastların dikumil peroksidin-0.5kütlo \% va ya kükürdün 5.0 kütla \% qatılığında alınması mümkündür. Müəyyən olunmuşdur ki, butil kauçukun miqdarı ASPE+PP qarışı̆̆ında 10, 20, 30, 40 kütla \% olduqda yumşalma temperaturu termomexaniki tacrübə göstəricilarina əsasən - 125, 107, 89, $78^{\circ} \mathrm{C}$ uyğun olaraq dəyişir.

Açar sözlor: dartılmada möhkəmlik həddi, modifikasiya, dinamik elastoplastlar, nisbi uzanma 


\title{
РЕАКЦИОННАЯ ЭКСТРУЗИЯ ДИНАМИЧЕСКИХ ЭЛАСТОПЛАСТОВ НА ОСНОВЕ ТЕРМОПЛАСТИЧНЫХ ПОЛИОЛЕФИНОВ И БУТИЛКАУЧУКА
}

\author{
3.Н. Гусейнова, Н.Т. Кахраманов, А.А. Гасанова, Х.В. Аллахвердиева, \\ Ф.A. Мустафаева, * В.C. Осипчик
}

Институт полимерных материалов Начиональной АН Азербайджана AZ 5004 Сумгайыт, ул С. Вургуна, 124; e-mail: najaf1946@ rambler.ru *Российский химико-технологический университет им.Д.И. Менделеева 127047, г.Москва, Миусская площадь, д.9

Рассмотрено влияние конщентрации бутилкаучука и вулканизующих агентов на технологический проиесс реакиионной экструзии эластопластов на основе смеси термопластичных полиолефинов. Механохимический синтез динамически вулканизованных эластопластов осуществляли в процессе реакционной экструзии. Экструдер одношнековый с отношением L/D = 24, состоит из 4-х зон: зоны загрузки, зоны сжатия, зоны дозирования и головки экструдера. Число оборотов шнека регулировали с помощью асинхронного двигателя. Головка оснащена с помощью щелевой приставки, позволяющей получать непрерывные листы толщиной 2 мм и шириной 100 мм. В качестве термопластичных полиолефинов использовали полиэтилен низкой плотности, полипропилен. Вулканизацию полимерных смесей проводили с использованием дикумилпероксида и серы. Механохимический синтез эластопластов проводили при различных температурах зон материального ичилиндра и давлении экструзии. Представлены результаты исследования влияния параметров проиесса экструзии на скорость течения расплава эластопластов. Для смеси полиэтилена низкой плотности и бутилкаучука оптимальный температурный режим по зонам материального цилиндра варьировали в пределах 100-150 ${ }^{\circ} \mathrm{C}$, а давление экструзии - 5.2-7.0 МПа. Для смеси полипропилена и бутилкаучука температурный режим варьировался в пределах 140 $210^{\circ} \mathrm{C}$ и давление экструзии - 7.2-9.4 МПа. Для придания полимерным смесям эластопластических свойств в их состав вводились такие вулканизующие агенты, как дикумил пероксид и сера. Изучено селективное влияние вулканизующих агентов на характер изменения технологических параметров реакиионной экструзии и индекса текучести расплава. Было обнаружено, что динамические вулканические эластопласты с уникальной совместимостью структур и свойств могут быть получены при концентрации дикумил пероксида-0.5\%масс. или серы-5.0\%масс.. Установлено также, что при конщентрации бутилкаучука в составе смеси ПЭНП+ПП - 10, 20, 30, 40\%масс. температура размягчения, по данным термомеханических испытаний, изменяется соответственно в пределах - $125,107,89,78^{\circ} \mathrm{C}$.

Ключевые слова: разрушающее напряжение, модификачия, динамические эластопласты, относительное удлинение. 